\title{
The influence of landscape context on the production of cultural ecosystem services
}

\author{
Kim C. Zoeller ${ }^{\circledR} \cdot$ Georgina G. Gurney \\ Graeme S. Cumming
}

Received: 8 March 2021 / Accepted: 27 January 2022 / Published online: 3 February 2022

(C) The Author(s) 2022

\begin{abstract}
Context Recent efforts to apply sustainability concepts to entire landscapes have seen increasing interest in approaches that connect socioeconomic and biophysical systems. Evaluating these connections through a cultural ecosystem services lens clarifies how different spatiotemporal scales and levels of organisation influence the production of cultural benefits. Currently, however, the effects of multi-level and multi-scale ecological variation on the production of cultural benefits have not yet been disentangled.

Objectives To quantify the amount of variation in cultural ecosystem service provision by birds to birders that is due to landscape-level attributes.

Methods We used data from 293 birding routes and 101 different birders in South African National Parks to explore the general relationships between birder responses to bird species and environmental conditions, bird-related observations, the biophysical attributes of the landscape and their effect on birdrelated cultural benefits.
\end{abstract}

K. C. Zoeller $(\bowtie) \cdot$ G. G. Gurney · G. S. Cumming Australian Research Council Centre of Excellence for Coral Reef Studies, James Cook University, Townsville, QLD 4811, Australia e-mail: kim.zoeller@my.jcu.edu.au

K. C. Zoeller · G. S. Cumming Percy FitzPatrick Institute, University of Cape Town, Rondebosch, Cape Town 7701, South Africa
Results Biophysical attributes (particularly biome, vegetation type, and variance in elevation) significantly increased the percentage of variance explained in birder benefits from 57 to $65 \%$, demonstrating that birder benefits are derived from multi-level (birds to ecosystems) and multi-scale (site to landscape) social and ecological interactions.

Conclusions Landscape attributes influence people's perceptions of cultural ecosystem service provision by individual species. Recognition of the complex, localised and inextricable linkage of cultural ecosystem services to biophysical attributes can improve our understanding of the landscape characteristics that affect the supply and demand of cultural ecosystem services.

Keywords Landscape variation - Biophysical attributes $\cdot$ Cultural ecosystem services $\cdot$ Birds

\section{Introduction}

Recent efforts to apply sustainability concepts to entire landscapes have demonstrated an increasing interest in approaches that connect socioeconomic and biophysical aspects of landscape change (Mao et al. 2020). One widely used approach for thinking about landscape sustainability is the ecosystem services framework, which focuses on the linkages between people and nature, and specifically, the capacity of ecosystems to deliver benefits essential 
to human wellbeing (MA 2005; Bachi et al. 2020; Bruley et al. 2021). The interaction between ecological systems and social systems in the production of ecosystem services forms a biocultural feedback loop, where landscape condition is shaped by perceptionbased preferences for particular ecosystem services that contribute to human wellbeing (Fig. 1) (Maffi and Woodley 2010; Tengberg et al. 2012; Agnoletti and Rotherham 2015).

While the role of biophysical factors in driving ecosystem service production (such as sequestration capacity of a peat bog or timber production in a forest) has been well established across a range of different scales, the role of social processes in the receipt of ecosystem benefits at different levels (e.g. organisms to ecosystems) and scales (e.g. site to landscape) has received limited attention (Bruley et al. 2021). Framing ecosystem services through people's connection to the environment is not a novel concept (Fish et al. 2016; Tew et al. 2019), but the effects of multi-level and multi-scale ecological variation on the production of cultural benefits have not yet been disentangled. It thus remains unclear how people experience ecosystem benefits that are produced over multiple scales and levels of organization and which kinds of benefit depend primarily on interactions with individual organisms, populations, communities, ecosystems, or landscapes respectively.

We explore the concept of multi-level and multiscale organisation in the production of ecosystem services through a cultural ecosystem services lens (Fig. 1). Cultural ecosystem services are non-material benefits such as aesthetic values, spiritual fulfilment, tourism and recreation (Chan et al. 2012). They are co-produced through the interactions between people (in social systems) and their environment (ecological systems) (Fish et al. 2016), delivering benefits that have direct contributions to human wellbeing (Fig. 1) (Fischer and Eastwood 2016). Ecological systems comprise multiple levels of ecological organisation. We focused particularly on three levels (and corresponding scales) relating to the provision of cultural ecosystem services: species, community, and landscape (Fig. 1). While the relationship between scales and levels in ecological systems is complex, we use conventional levels of ecological organisation that should exhibit a hierarchical relationship to ecological processes and associated spatial and temporal scales (Allan 1990). Thus, species and communities are nested within landscapes; landscape-level biophysical attributes support species propagation through the provision of resources like food and habitat (Aalders and Stanik 2019).

We used the cultural service of bird-watching as an accessible case study from which to explore how multi-level and multi-scale interactions are related to ecosystem service production. The distributions of birds vary in geographic space, and the benefits associated with birdwatching are well-established and globally prevalent (Sekercioglu 2002; Whelan et al. 2015; Graves et al. 2019). Bird-watching by its nature appears to focus on the level of individual organisms of different species. However, previous research has suggested that there may be a vital link missing in

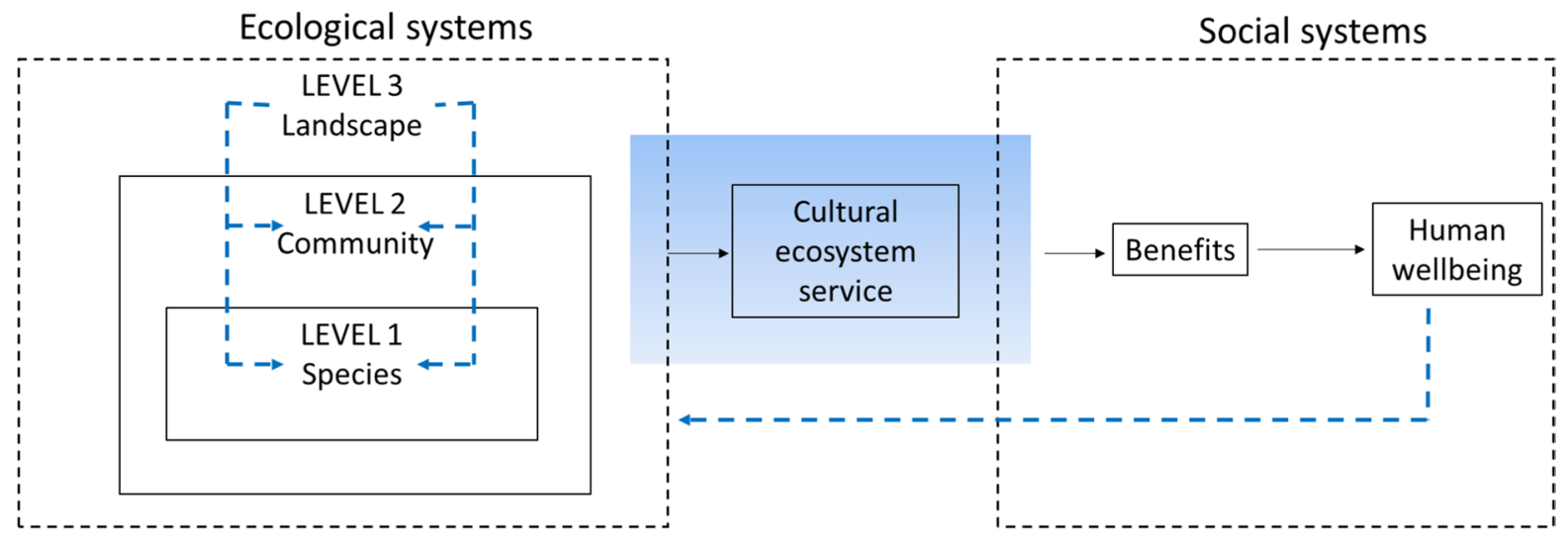

Fig. 1 The flow of cultural ecosystem service benefits from ecological systems to social systems using a simplified ecosystem cascade model 
our understanding of the relationship between landscape-level processes and the benefits associated with birdwatching (Cumming and Maciejewski 2017). A recent study found that benefits related to species observations alone accounted for only $27 \%$ of variance in birder benefits, while including birder expectations and responses to environmental conditions increased the proportion of variance explained to 57\% (Cumming and Maciejewski 2017). Some previous research has identified aesthetic benefits associated with birding which are related to certain elements of nature, such as water bodies or complex terrain (Chettri et al. 2005; Andersson et al. 2015). The extent to which variation in landscape-level attributes supports the provision of birder benefits remain unclear, however, and has not been previously quantified relative to the direct benefits derived from seeing birds. We hypothesized that a significant proportion of the remaining $43 \%$ of unexplained variation in Cumming and Maciejewski's (2017) study might be explained by landscape-level characteristics, particularly biophysical attributes such as elevation that might contribute to the benefits associated with birding (Fig. 1). Connecting birder benefits with the biophysical attributes of landscapes provides important insights into how perceptions of cultural ecosystem services (and thus, benefits experienced) by people are mediated by the multi-level and multi-scale structure of ecological systems (Plieninger et al. 2013).

\section{Methods}

\section{Bird occurrence data}

To determine the relationships between the subjective experiences of the birders, their bird-related observations and quantifiable biophysical attributes of the landscape, we used the dataset for bird occurrences and birder experiences described in Cumming and Maciejewski (2017). Data were collected along 293 routes from all 19 of South Africa's National Parks: Addo, Agulhas, Augrabies, Bontebok, Camdeboo, Garden Route, Golden Gate, Karoo, Kgalagadi, Kruger, Mapungubwe, Marakele, Mokala, Mountain Zebra, Namaqua, Richtersveld, Table Mountain, Tankwa-Karoo, and West Coast from 2016 to 2017 (Fig. 2) (Cumming and Maciejewski 2017). To collect these data, amateur birders went birding twice a day for at least two hours over a minimum distance of $2 \mathrm{~km}$ while wearing a Garmin GPS Forerunner 310XT wristwatch. After completing each route, the track was downloaded from the wristwatch. The amateur birders submitted a list of birds they saw and/ or heard, and completed a satisfaction survey (see Sect. Surveys).

In total, 101 people participated in the study. Most participants were experienced and well-established birders in South Africa, where the mean number of years of birding experience was 18.6 ( \pm SD 12.3), and the mean number of South African birds seen by participants was 483 ( \pm SD 201) (Cumming and Maciejewski 2017). While there was an even divide of gender (50 female and 51 male), there was limited variability in socio-demographic characteristics of participants (specifically an over-representation of white participants), reflecting broader demographic patterns of National Park visitors in South Africa (Scholtz et al. 2015).

\section{Surveys}

The satisfaction surveys completed by amateur birders comprised a pre-trip and post-trip questionnaire. The pre-trip questionnaire was a short survey on their birding expectations. Longer surveys were conducted for the post-trip survey, in which respondents scored their birding experience using a Likert-type scale from 1 to 10 (i.e., terrible to excellent) to provide a single measurement of overall satisfaction of their birding experience. We term this 'birder benefit' (following Cumming and Maciejewski 2017), recognising that it is likely to be a relatively coarse correlate of the actual psychological benefit received. Amateur participants also provided detailed explanations for the benefit scores that they assigned, defined as perception-based birding experiences. These were coded, using an inductive thematic analytical approach, into five summary categories: (1) subjective impressions of the overall number and nature of birds seen; (2) comfort variables, such as weather, company, and ease of movement along the route; (3) impressions directly related to the particular species seen, such as rare and endemic birds, and specific behavioural interactions (e.g., predation, competition, mating); (4) subjective landscape correlates of the experience, such as the beauty of the surroundings and general visibility; and (5) educational value of the experience, 

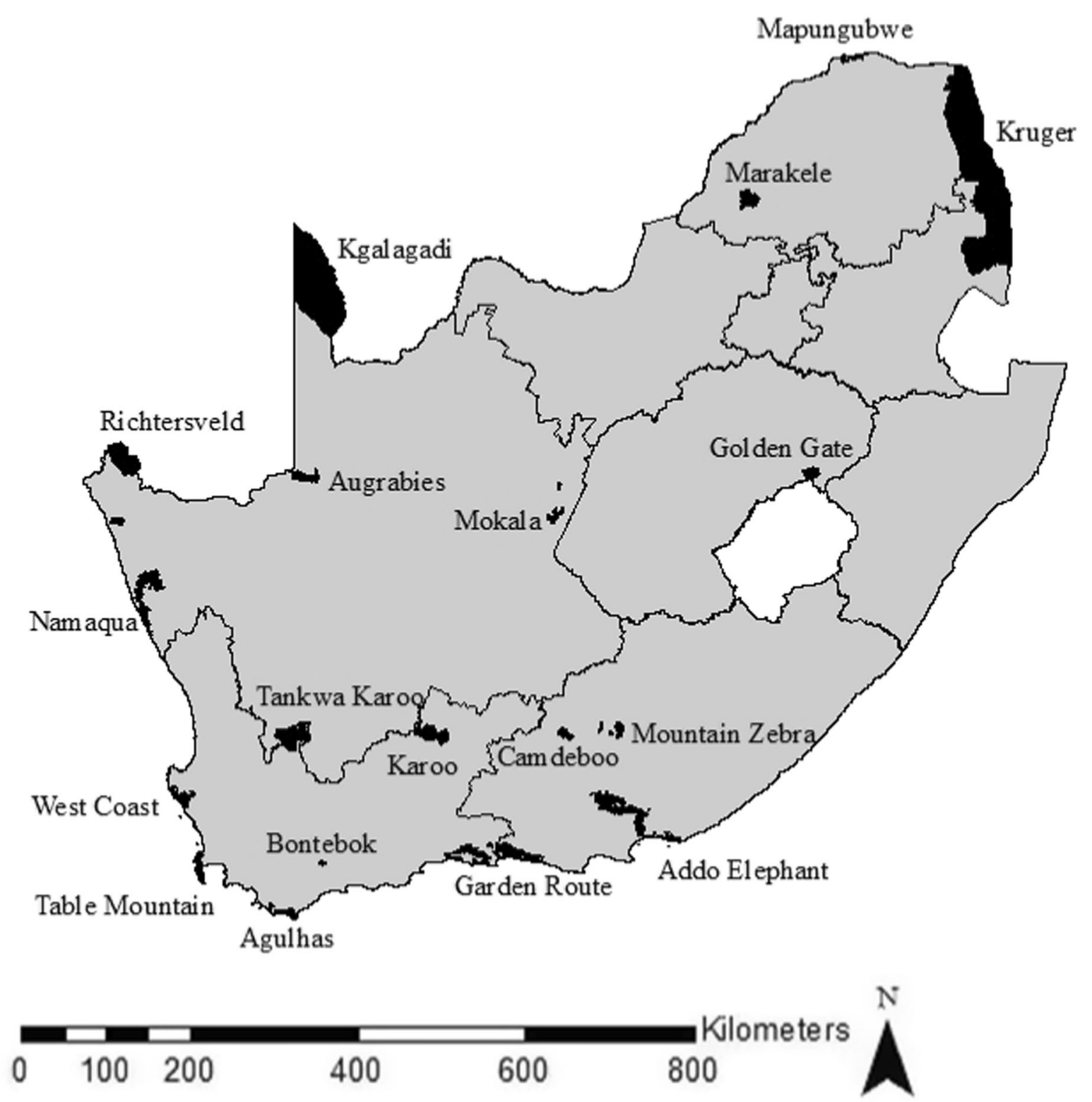

Fig. 2 Map of South African National Parks

such as new birds learned. To determine which categories contributed to birder benefits, we excluded reasons that explained less than 5\% of their variance, as determined by Cumming and Maciejewski (2017). The subsequent reasons included in the final analysis under the first four categories were: (1) perceived species richness, low diversity of species, and low abundance of species; (2) bad weather, good weather and unfavourable route; (3) unexpected sighting of a species and a good sighting of species; and (4) boring, monotonous landscape and interesting, diverse landscape (see Table 1 for further explanations of these variables).

Landscape attribute data

The parks in this study include an exceptionally diverse range of habitats, ranging from coastal to 
Table 1 Landscape characteristics, how they were measured and how these characteristics might influence perception of ecosystem services, with examples

\begin{tabular}{|c|c|c|}
\hline Landscape characteristics & Measurement & Mechanism and examples \\
\hline Biome & Categorical & $\begin{array}{l}\text { Biomes are defined by the dominant plant growth form and associated climatic } \\
\text { thresholds (Conradi et al. 2020). From an ornithological perspective, biomes } \\
\text { create specific conditions for which bird species are adapted (Steven et al. } \\
\text { 2017). Specific plant growth forms in biomes may be associated with rare, } \\
\text { endangered or common species (Chettri et al. 2005) }\end{array}$ \\
\hline Elevation & $\begin{array}{l}\text { Mean } \\
\text { Variance }\end{array}$ & $\begin{array}{l}\text { Higher elevation has been correlated with low species richness (Graves et al. } \\
\text { 2019). In addition, elevation might impede the field of view of birders, nega- } \\
\text { tively affecting their birding experience }\end{array}$ \\
\hline Roads & $\begin{array}{l}\text { Length } \\
\text { Presence/absence } \\
\text { Road type }\end{array}$ & $\begin{array}{l}\text { The effect of roads on birding include higher rates of disturbance and disruption } \\
\text { of bird activity }\end{array}$ \\
\hline Water body & $\begin{array}{l}\text { Presence/absence } \\
\text { Water body type }\end{array}$ & $\begin{array}{l}\text { The importance of water bodies for birdwatching has been well documented in } \\
\text { ecosystem service literature (Raudsepp-Hearne et al. 2010). Bodies of water } \\
\text { may also contribute positively to the aesthetic experience of birdwatching } \\
\text { (Chettri et al. 2005) }\end{array}$ \\
\hline Vegetation type & Categorical & $\begin{array}{l}\text { Vegetation type is classified according to criteria including physiognomy, } \\
\text { structure, plant functional traits and species composition (De Cáceres and } \\
\text { Wiser 2012). Local vegetation influences the distribution of bird communities } \\
\text { through habitat heterogeneity and resource availability (Belaire et al. 2015) }\end{array}$ \\
\hline Land cover & Categorical & $\begin{array}{l}\text { Land cover is defined by environmental attributes (including landform, altitude, } \\
\text { soil) and specific technical attributes (including cultivated areas) which influ- } \\
\text { ences the availability of habitats for birds and therefore the spatial distribution } \\
\text { of bird communities (Chettri et al. 2005; Di Gregorio 2005; Kolstoe et al. } \\
\text { 2018) }\end{array}$ \\
\hline Species richness & Count & \multirow{3}{*}{$\begin{array}{l}\text { Evidence has suggested that species richness, diversity and abundance of bird } \\
\text { communities affects perceptions of birding experiences (Booth et al. 2011; } \\
\text { Cumming and Macijewski, 2017) }\end{array}$} \\
\hline Low diversity & Count & \\
\hline Low abundance & Count & \\
\hline Unexpected species & Perception & \multirow[b]{2}{*}{$\begin{array}{l}\text { Unexpected species refers to a bird species that, given the terrain, area or time, } \\
\text { was unexpected, but nevertheless a pleasant surprise to the birder. Sightings of } \\
\text { unexpected species or a good sighting of species (through e.g. clear observa- } \\
\text { tions or witnessing particular behaviours) are highly correlated with birder } \\
\text { benefits since birders may become conditioned to cultural ecosystem service } \\
\text { provision by the same species in different locations (Cumming and Maciejew- } \\
\text { ski 2017) }\end{array}$} \\
\hline Good sighting of species & Perception & \\
\hline Good weather & Perception & \multirow{3}{*}{$\begin{array}{l}\text { External variables such as weather and perceptions of landscape has been } \\
\text { shown to significantly influence birder benefits. For example, Cumming and } \\
\text { Maciejewski (2017) found that incorporating these variables with biodiversity } \\
\text { measures increased the percetange of variance explained in birder benefits } \\
\text { from } 27 \text { to } 57 \%\end{array}$} \\
\hline Bad weather & Perception & \\
\hline Interesting diverse landscape & Perception & \\
\hline
\end{tabular}

highland and forested to desert. To determine the contribution of biophysical attributes to amateur birder benefits, the birding route coordinates were converted into a shapefile and analysed in a Geographic Information System (GIS). We added a $5 \mathrm{~km}$ buffer around each route to mirror the field of view of standard binoculars and account for biophysical attributes that participants might have encountered while birding, which could have included views across valleys or over the ocean. From existing maps of biophysical landscape attributes, we extracted data on features that have been shown to influence birder enjoyment: biome, elevation, roads, water bodies, vegetation type and land cover (see Table 1). Each of the variables within each buffer zone was measured for each route.

\section{Data analysis}

To reduce the dimensionality of our data, we screened for redundancy in variables with over 40 categories 
(i.e., vegetation type and land cover) by separately coding each independent variable as a set of individual categories and removing non-significant categories from the multivariate model. We reran the analysis three times, removing non-significant variables each time in a stepwise process, to identify the model that best fitted our data based on the lowest AIC value.

We tested for a relationship between birder benefits and landscape characteristics using multivariate mixed-effects linear models to take account of covariance effects within the data. For these models, we used the continuous rating data of satisfaction scores (birder benefits) as our response variable, and perception-based and biophysical landscape attributes as predictors. To account for the nested structure of our data (multiple birders in each National Park), we included location (National Park) as a random effect in the model. We also ran ANOVAs to determine whether there were differences in birder benefits and species richness according to biome, and post-hoc Tukey tests to see where those differences occurred.

\section{Results}

The multivariate analysis indicated that $65 \%$ of variance in birder benefits was explained by a combination of subjective responses by participants at the species scale ("bird species responses"), perceptionbased responses at the landscape scale ("environmental responses") and biophysical attributes, specifically biome, vegetation type and variance in elevation $\left(\mathrm{r}^{2}=0.65 \quad\right.$ AIC $=1012, \quad$ deviance $\left.=933.6, \quad \mathrm{df}=273\right)$ (Table 2). Adding landscape variables increased our ability to predict cultural service provisioning by a significant $38 \%$ relative to models that only included bird responses, and $8 \%$ relative to models that included bird responses and perception-based responses at the landscape scale.

The dominant biophysical attribute that explained variance in birder benefits in our model was biome, with all biome types being strong, positive predictors of route ranking (Table 2). Based on birder benefit averages (overall satisfaction), routes in Grassland and Fynbos biomes were favoured by participants. Gabbro Grassy Bushveld and Tankwa Karoo emerged as significant vegetation types in our multivariate model. These vegetation types are characteristic of
Savanna and Succulent Karoo biomes respectively. On average, birders in Succulent Karoo reported lower benefits than all other biomes, although this difference was only significant when compared to routes in Savanna biomes $(\mathrm{DF}=6, \mathrm{~F}-\mathrm{value}=2.161$, $\mathrm{p}=0.047$ ) (Fig. 3). Differences in species richness according to biome were also significant $(\mathrm{DF}=6$, $\mathrm{F}$-value $=10.01, \mathrm{p}=5.72 \mathrm{e}-10$ ), specifically between Grassland and Azonal vegetation and Nama Karoo; Nama Karoo and Savanna; and between Succulent Karoo and Azonal Vegetation, Fynbos, Grassland and Savanna $(\mathrm{p}<0.05)$. On average, species richness was greatest in Grasslands and lowest in Succulent Karoo. In addition to biome and vegetation, variance in elevation had a significant positive effect on route ranking, suggesting that routes with more complex terrain were preferred by birders. Despite the expectation that additional biophysical attributes would account for variance in the model, roads, water bodies and land cover types (keeping in mind that all surveys were undertaken in protected areas in 'natural' habitats) did not have a significant effect on benefits.

With the exception of 'good weather', responses by participants to observations of bird species and biophysical attributes were dominant and consistently significant in predicting amateur birder rankings of birding routes. Perceptions of the diversity and abundance of birds observed had a significant effect on reported benefits.

\section{Discussion}

Our results show that birder benefits were related to biome, vegetation type and perceptions of the bird population observed, the landscape, and the weather. Including biophysical attributes with perceptionbased birding experiences increased the percentage of variance explained in birder benefits from 57 (Cumming and Maciejewski 2017) to $65 \%$, supporting the hypothesis that a small but significant proportion of birder benefit is produced from multi-level and multiscale social-ecological interactions. We would expect the influence of the surrounding landscape to increase in areas that are more heavily impacted by people (e.g., agricultural landscapes and urban areas) than National Parks. These results provide support for the consideration of landscape-level attributes in addition to species observations, even in cases where cultural 
Table 2 Summary table of estimates, standard error (SE), t-value and p-value of the multivariate linear model $(n=273)$

\begin{tabular}{|c|c|c|c|c|}
\hline & Estimate & Std. Error & t value & $\operatorname{Pr}(>|t|)$ \\
\hline (Intercept) & 2.148926 & 1.010512 & 2.127 & $0.034353 *$ \\
\hline \multicolumn{5}{|l|}{ Biome } \\
\hline Forest & 2.429732 & 0.748238 & 3.247 & $0.001311 * *$ \\
\hline Fynbos & 3.068522 & 0.580547 & 5.286 & $2.57 \mathrm{E}-07 * * *$ \\
\hline Grassland & 3.694464 & 1.047803 & 3.526 & $0.000495 * * *$ \\
\hline Nama-Karoo & 3.069363 & 0.554283 & 5.538 & 7.21E-08*** \\
\hline Savanna & 3.214063 & 0.553506 & 5.807 & $1.77 \mathrm{E}-08 * * *$ \\
\hline Succulent Karoo & 2.474237 & 0.536446 & 4.612 & $6.13 \mathrm{E}-06 * * *$ \\
\hline \multicolumn{5}{|l|}{ Elevation } \\
\hline Mean & -0.067674 & 0.057398 & -1.179 & 0.239412 \\
\hline Variance & 0.323834 & 0.084162 & 3.848 & $0.000148 * * *$ \\
\hline \multicolumn{5}{|l|}{ Roads } \\
\hline Road length & 0.137437 & 0.537389 & 0.256 & 0.798337 \\
\hline Presence/absence & -0.064289 & 0.84461 & -0.076 & 0.939382 \\
\hline \multicolumn{5}{|l|}{ Road type } \\
\hline Primary & -0.438707 & 0.429158 & -1.022 & 0.307567 \\
\hline Secondary & -0.25979 & 0.348555 & -0.745 & 0.45671 \\
\hline Service & -0.822557 & 1.394558 & -0.59 & 0.55579 \\
\hline Tertiary & 0.334996 & 0.476005 & 0.704 & 0.482179 \\
\hline Track & -0.520123 & 0.689357 & -0.755 & 0.451196 \\
\hline Trunk & -0.018427 & 0.439869 & -0.042 & 0.966615 \\
\hline Unclassified & -0.212259 & 0.333307 & -0.637 & 0.524771 \\
\hline Unsurfaced & 0.621175 & 1.033431 & 0.601 & 0.548285 \\
\hline \multicolumn{5}{|l|}{ Water bodies } \\
\hline Water presence & -0.011871 & 0.220424 & -0.054 & 0.957091 \\
\hline \multicolumn{5}{|l|}{ Water body type } \\
\hline Dry & -0.597705 & 0.83542 & -0.715 & 0.47494 \\
\hline Non-Perennial & -0.16865 & 0.431912 & -0.39 & 0.696491 \\
\hline Perennial & 0.023209 & 0.493382 & 0.047 & 0.962515 \\
\hline Unknown & -0.501586 & 0.522773 & -0.959 & 0.33817 \\
\hline River length & -1.367543 & 4.470527 & -0.306 & 0.759912 \\
\hline River area & 12.327655 & 89.917848 & 0.137 & 0.891054 \\
\hline \multicolumn{5}{|l|}{ Vegetation type } \\
\hline Gabbro Grassy Bushveld & 1.993262 & 0.684651 & 2.911 & $0.003896 * *$ \\
\hline Kimberley Thornveld & 0.905013 & 0.587533 & 1.54 & 0.124631 \\
\hline Tanqua Karoo & 1.819932 & 0.475425 & 3.828 & $0.00016^{* * *}$ \\
\hline \multicolumn{5}{|l|}{ Land cover } \\
\hline Low shrubland (Nama Karoo) & -0.766333 & 0.451225 & -1.698 & 0.090583 \\
\hline \multicolumn{5}{|l|}{ Bird species responses } \\
\hline Richness & 0.06887 & 0.009509 & 7.243 & 4.49E-12*** \\
\hline Low diversity & -0.525371 & 0.103976 & -5.053 & $7.98 \mathrm{E}-07 * * *$ \\
\hline Low abundance & -0.321921 & 0.099448 & -3.237 & $0.001357 * *$ \\
\hline Unexpected species & 0.350256 & 0.107758 & 3.25 & $0.001297 * *$ \\
\hline Good sighting of species & 0.33692 & 0.094402 & 3.569 & $0.000423^{* * *}$ \\
\hline \multicolumn{5}{|l|}{ Environmental responses } \\
\hline Good weather & 0.210489 & 0.134004 & 1.571 & 0.117394 \\
\hline Bad weather & -0.358387 & 0.090605 & -3.955 & $9.74 \mathrm{E}-05^{* * *}$ \\
\hline
\end{tabular}


Table 2 (continued)

\begin{tabular}{lcccc}
\hline & Estimate & Std. Error & $\mathrm{t}$ value & $\operatorname{Pr}(>|\mathrm{t}|)$ \\
\hline Interesting diverse landscape & 0.421013 & 0.103034 & 4.086 & $5.77 \mathrm{E}-05^{* * *}$ \\
\hline
\end{tabular}

Predictor variables of birder benefits were assigned significant codes: 0 ‘***’ 0.001 '**’ 0.01 ‘ $*$ ' 0.05 '? 0.1 ' 1
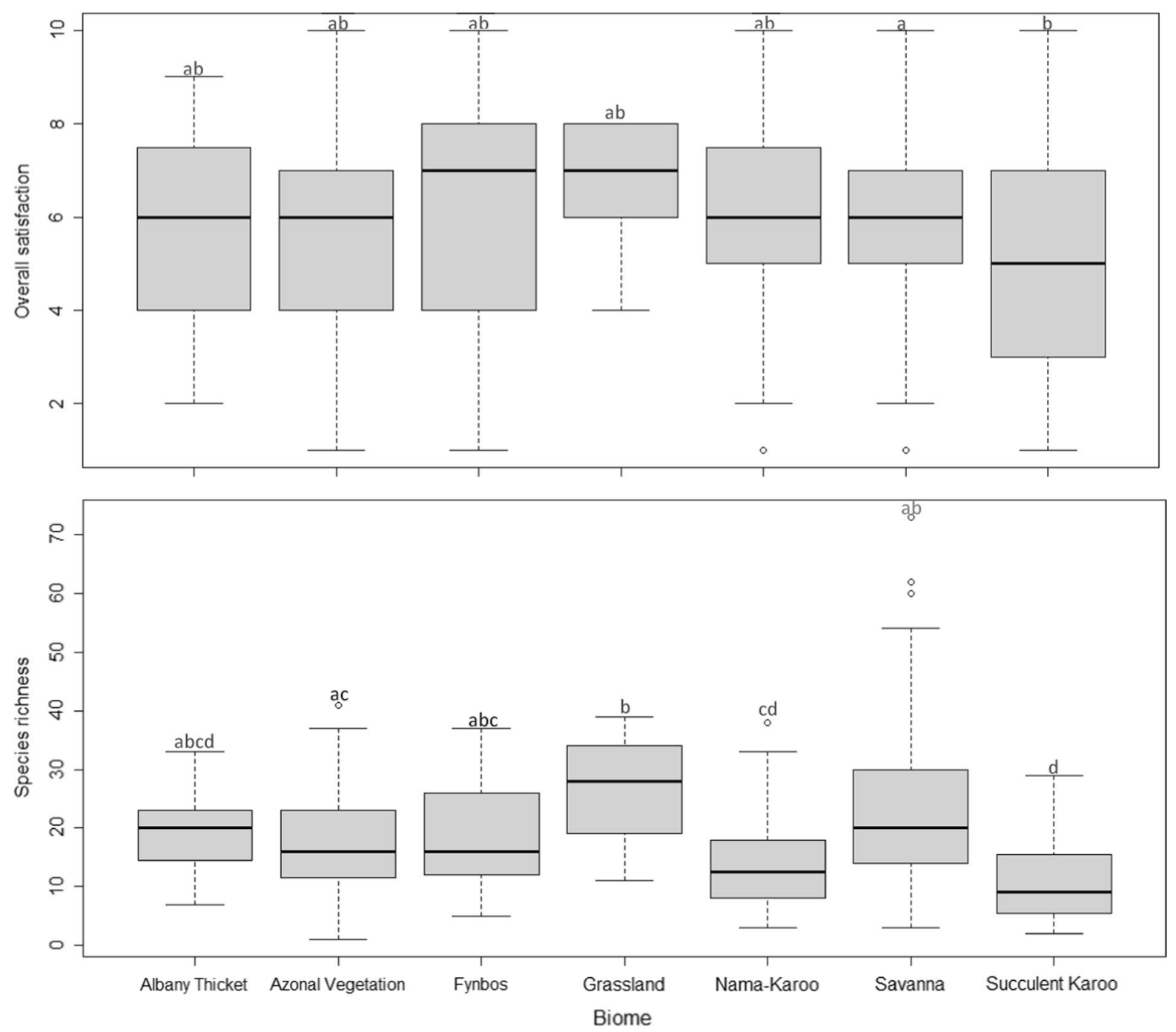

Fig. 3 Comparison by biome of amateur overall satisfaction score with birding routes (top panel) and number of bird species seen (lower panel). Clusters sharing a letter are not statistically different from each other $(\mathrm{p}<0.05)$

service provision appears to be highly dependent on individual organisms, to more accurately reflect the processes that result in the co-production of cultural ecosystem service benefits.
Despite their contribution to variance explained in birder benefits, only three biophysical attributes added significant explanatory power to the model. The primary explanatory biophysical variables in this model were biome and vegetation type. The importance of 
biomes in accounting for variance in birder benefits highlights potential connections between individuallevel and landscape-level social-ecological interactions (typically occurring at fine and broad scales respectively). Biomes are defined by the dominant plant growth form and associated climatic thresholds (Conradi et al. 2020) which create specific conditions to which bird species are adapted (Chettri et al. 2005; Steven et al. 2017; Filloy et al. 2019). In the case of habitat specialists, specialised adaptations enable certain bird species to survive under specific conditions (e.g. cutaneous evaporation in desert birds) (Gerson et al. 2014). Landscape-level processes influencing biome distribution thus also contribute to the receipt of birder benefits at the species level.

Birder benefits in the Succulent Karoo were not significantly different from other biome types. The Succulent Karoo, which features the Tankwa Karoo vegetation type, is located in a biodiversity hotspot (CEPF 2001) that is characterised by fragile drylands that are highly susceptible to disturbance (Ament et al. 2017). Although species diversity was low in the Succulent Karoo, birder benefits did not generally differ compared to more speciose biomes (Cumming and Maciejewski 2017). These results suggest that birder benefits were not reduced in low diversity biomes, implying in turn that birders may adjust their expectations to fit specific landscapes (Cumming and Maciejewski 2017). In areas where the environment is harsh and organisms require more specialised adaptations to survive (e.g., deserts, mountain-tops), cultural ecosystem services associated with species and communities may be outweighed by landscape level attributes such as biome and vegetation type (Cumming and Maciejewski 2017).

Cultural ecosystem services are amongst the most valued products of ecosystems (Orenstein et al. 2015), but are challenging to manage since cultural values are subjective (Tew et al. 2019). Linking quantifiable landscape attributes with perception-based measures of the landscape may provide insight into the biophysical drivers of people's perceptions which can help prioritise landscape management decisions. For example, "interesting, diverse landscape" was a significant explanatory variable in our model. The attributes of a landscape that promote the perception of an interesting and diverse landscape can be linked to biome, vegetation type and variation in elevation since these biophysical attributes were also significant. Assessing cultural ecosystem services by considering all levels of ecological organization can provide insight into people's preferences and perceptions that drive the co-production of ecosystem services (Katz-Gerro and Orenstein 2015).

However, it is important to note that individual perception is not uniform across a given population. For example, amateur birders have been found to be generally more interested in non-birding components of a birding experience than experts (Hvenegaard 2002). (Katz-Gerro and Orenstein 2015). Different social groups may preferentially engage with different levels of ecological organization to the extent that attributes that contribute to an "interesting, diverse landscape" could differ between ecosystem users (Katz-Gerro and Orenstein 2015). Previous research has shown that perceptions of cultural ecosystem services associated with birds are likely to vary significantly across socio-demographic characteristics, such as age, gender, race language and education (Zoeller et al. 2021). For example, in South Africa, Xhosaspeakers were shown to perceive visual traits of birds (including inter alia plumage colour and body size) more frequently than English-speakers (Zoeller et al. 2020, 2021). Avitourism tends to attract an older demographic with high enough income to afford travel and park entry fees (Steven et al. 2017). Indeed, as reflected for our respondents, typical visitors to National Parks in South Africa average 46 years old, speak either English or Afrikaans, are married, and possess higher education qualifications (Scholtz et al. 2015). Understanding how variation in birders' identity relates to perceptions of birder benefits and their multi-level biophysical drivers provides an important avenue for future research (Tengberg et al. 2012). Many birders fall into a relatively influential and empowered demographic; equitable decisions around biodiversity conservation and landscape protection will ultimately require inclusion of the values and preferences held by the full spectrum of society (Lau et al. 2018).

Understanding the influence of landscape characteristics on birder benefits requires consideration of the nested relationship between species, communities and landscape. While this study disentangled the individual effects of different levels of ecological organisation to better understand their contribution to birder benefits, components of ecological systems are not independent of each other (Suarez-Rubio and 
Thomlinson 2009; Filloy et al. 2019). For instance, while the results suggested that biome, vegetation type and variance in elevation were significantly related to birder benefits, these biophysical attributes also affect the assemblage of bird communities through hierarchical relationships at different scales and levels (Aalders and Stanik 2019). In addition, social systems exert a critical selective pressure on ecological systems (Tengberg et al. 2012), suggesting that the provision of birder benefits also depends on demand from birders. Consequently, the cultural benefits derived from birdwatching are produced from complex social-ecological interactions that occur at multiple levels and scales even when cultural services are ostensibly delivered at the species level.

We have provided evidence for the existence of significant, measurable, multi-level spatial influences on cultural ecosystem services associated with birding. An important consideration going forward would be to explicitly account for seasonal shifts in bird assemblages and their impact on cultural benefits received from ecosystems, particularly in relation to migratory species. While we conducted sampling evenly throughout summer and winter (Cumming and Maciejewski 2017), we did not measure species-specific responses to seasonal changes and their influence on birder benefits (Graves et al. 2019). Similarly, we did not explore how seasonal shifts may impact benefits associated with landscape-level responses. For example, perceptions of birder benefits may be lower during dry periods than flowering seasons, through the formation of concentrations of nectarivorous birds and changes in vegetation-related aesthetics (Chettri et al. 2005). Exploring temporal variation in conjunction with spatial contexts may therefore provide further insight into birder benefits.

Understanding cultural ecosystem services at the landscape-level and implementing conservation measures to protect valuable biophysical attributes can mitigate against potential threats to ecosystem service delivery (Schaich et al. 2010). Although ecosystem services are generated within the landscape, there is little understanding of landscape-ecosystem service connections (Andersson et al. 2015). We found that biophysical attributes of the landscape influence the perception of cultural ecosystem service provision at the species scale and thus need to be explicitly considered in ecosystem service assessments, even where a cultural service is heavily linked to individual organisms. Components of landscapes interact with one another, resulting in a landscape mosaic comprising a composite of different attributes (Daniels 1994). Landscapes are often perceived as a whole rather than the sum of individual biophysical attributes (Fagerholm et al. 2019). Safeguarding the provision of birder benefits therefore requires supporting variation in spatial contexts and across multiple scales (Graves et al. 2019). Recognition of the complex, localised and inextricable linkage of cultural ecosystem services to landscape features can also improve our understanding of landscape characteristics that affect the supply and demand of cultural ecosystem services (Potschin et al. 2013; Keller and Backhaus 2019).

Acknowledgements We thank the many amateur birders who participated in birding surveys and enthusiastically volunteered their time and expertise. We would also like to extend our gratitude to Dominic Henry, Kristine Maciejewski, Robyn Milne and Alice McClure for field assistance and support on sampling protocol. This research was funded by the South African National Research Foundation (NRF) through a Blue Skies grant to GSC, by the DST/NRF Centre of Excellence at the Percy FitzPatrick Institute, the ARC Centre of Excellence for Coral Reef Studies and James Cook University.

Author contributions $\mathrm{KCZ}$ and $\mathrm{GSC}$ - designed research; $\mathrm{KCZ}$ - performed research; $\mathrm{KCZ}$ - analysed data; and $\mathrm{KCZ}$, GSC and GGG-wrote the paper.

Funding Open Access funding enabled and organized by CAUL and its Member Institutions. This research was funded by the South African National Research Foundation (NRF) through a Blue Skies grant to GSC, by the DST/NRF Centre of Excellence at the Percy FitzPatrick Institute, the ARC Centre of Excellence for Coral Reef Studies and James Cook University.

Data availability (data transparency) Where storage will not compromise the anonymity of research participants, data will be deposited in the Dryad repository.

Code availability (software application or custom code) Not applicable.

\section{Declarations}

Conflict of interest The authors declare that they have no conflict of interest.

Ethical approval (include appropriate approvals or waivers) This study was granted approval through the University of Cape Town, permit number SFREC 48_2012.

Consent to participate (include appropriate statements) Not applicable. 
Consent for publication (include appropriate statements) Not applicable.

Open Access This article is licensed under a Creative Commons Attribution 4.0 International License, which permits use, sharing, adaptation, distribution and reproduction in any medium or format, as long as you give appropriate credit to the original author(s) and the source, provide a link to the Creative Commons licence, and indicate if changes were made. The images or other third party material in this article are included in the article's Creative Commons licence, unless indicated otherwise in a credit line to the material. If material is not included in the article's Creative Commons licence and your intended use is not permitted by statutory regulation or exceeds the permitted use, you will need to obtain permission directly from the copyright holder. To view a copy of this licence, visit http://creativecommons.org/licenses/by/4.0/.

\section{References}

Aalders I, Stanik N (2019) Spatial units and scales for cultural ecosystem services: a comparison illustrated by cultural heritage and entertainment services in Scotland. Landscape Ecol 34(7):1635-1651

Agnoletti M, Rotherham ID (2015) Landscape and biocultural diversity. Biodivers Conserv 24(13):3155-3165

Allen TF, Hoekstra TW (1990) The confusion between scaledefined levels and conventional levels of organization in ecology. J Veg Sci 1:5-12

Ament JM, Moore CA, Herbst M, Cumming GS (2017) Cultural ecosystem services in protected areas: understanding bundles, trade-offs, and synergies. Conserv Lett 10(4):440-450

Andersson E, McPhearson T, Kremer P et al (2015) Scale and context dependence of ecosystem service providing units. Ecosyst Serv 12:157-164

Bachi L, Ribeiro SC, Hermes J, Saadi A (2020) Cultural Ecosystem Services (CES) in landscapes with a tourist vocation: mapping and modeling the physical landscape components that bring benefits to people in a mountain tourist destination in southeastern Brazil. Tour Manag 77:104017

Belaire JA, Westphal LM, Whelan CJ, Minor ES (2015) Urban residents' perceptions of birds in the neighborhood: Biodiversity, cultural ecosystem services, and disservices. The Condor 117(2):192-202

Bruley E, Locatelli B, Lavorel S (2021) Nature's contributions to people: coproducing quality of life from multifunctional landscapes. Ecol Soc 26(1):12

Chan KMA, Satterfield T, Goldstein J (2012) Rethinking ecosystem services to better address and navigate cultural values. Ecol Econ 74:8-18

Chettri N, Deb DC, Sharma E, Jackson R (2005) The relationship between bird communities and habitat. Mt Res Dev 25(3):235-243

Conradi T, Slingsby JA, Midgley GF, Nottebrock H, Schweiger AH, Higgins SI (2020) An operational definition of the biome for global change research. New Phytol 227(5):1294-1306

Cumming GS, Maciejewski K (2017) Reconciling community ecology and ecosystem services: Cultural services and benefits from birds in South African National Parks. Ecosyst Serv 28:219-227

Daniels RR (1994) A landscape approach to conservation of birds. J Biosci 19(4):503-509

De Cáceres M, Wiser SK (2012) Towards consistency in vegetation classification. J Veg Sci 23(2):387-393

Di Gregorio A (2005) Land cover classification system: classification concepts and user manual: LCCS. Food \& Agriculture Org

Fagerholm N, Torralba M, Moreno G et al (2019) Crosssite analysis of perceived ecosystem service benefits in multifunctional landscapes. Glob Environ Chang 56:134-147

Filloy J, Zurita GA, Bellocq MI (2019) Bird diversity in urban ecosystems: the role of the biome and land use along urbanization gradients. Ecosystems 22(1):213-227

Fischer A, Eastwood A (2016) Coproduction of ecosystem services as human-nature interactions-an analytical framework. Land Use Policy 52:41-50

Fish R, Church A, Winter M (2016) Conceptualising cultural ecosystem services: a novel framework for research and critical engagement. Ecosyst Serv 21:208-217

Gerson AR, Smith EK, Smit B, McKechnie AE, Wolf BO (2014) The impact of humidity on evaporative cooling in small desert birds exposed to high air temperatures. Physiol Biochem Zool 87(6):782-795

Graves RA, Pearson SM, Turner MG (2019) Effects of bird community dynamics on the seasonal distribution of cultural ecosystem services. Ambio 48(3):280-292

Hvenegaard GT (2002) Birder specialization differences in conservation involvement, demographics, and motivations. Hum Dimens Wildl 7(1):21-36

Katz-Gerro T, Orenstein DE (2015) Environmental tastes, opinions and behaviors: social sciences in the service of cultural ecosystem service assessment. Ecol Soc 20(3):28

Keller R, Backhaus N (2019) Integrating landscape services into policy and practice-a case study from Switzerland. Landsc Res. https://doi.org/10.1080/01426397.2019. 1569218

Kolstoe S, Cameron TA, Wilsey C (2018) Climate, land cover, and bird populations: Differential impacts on the future welfare of birders across the pacific northwest. Agricul Res Eco Rev 47(2):272-310

Lau JD, Hicks CC, Gurney GG, Cinner JE (2018) Disaggregating ecosystem service values and priorities by wealth, age, and education. Ecosyst Serv 29:91-98

MA (2005) Millennium Ecosystem Assessment. Ecosystems and human well-being: synthesis. Island Press, Washington, DC

Maffi L, Woodley E (2010) Biocultural diversity conservation: a global sourcebook. Earthscan, London

Mao D, Ma Q, Zhou B-B (2020) Sustainability of human-environment systems through the lens of landscape. Springer, New York

Orenstein DE, Zimroni H, Eizenberg E (2015) The immersive visualization theater: a new tool for ecosystem assessment 
and landscape planning. Comput Environ Urban Syst 54:347-355

Plieninger T, Dijks S, Oteros-Rozas E, Bieling C (2013) Assessing, mapping, and quantifying cultural ecosystem services at community level. Land Use Policy 33:118-129

Potschin M, Potschin M, Haines-Young R, Haines-Young R (2013) Landscapes, sustainability and the placebased analysis of ecosystem services. Landscape Ecol 28(6):1053-1065

Raudsepp-Hearne C, Peterson GD, Tengö M et al (2010) Untangling the Environmentalist's Paradox: Why Is Human Well-being Increasing as Ecosystem Services Degrade? BioScience 60(8):576-589

Schaich H, Bieling C, Plieninger T (2010) Linking ecosystem services with cultural landscape research. Gaia-Ecol Perspect Sci Soc 19(4):269-277

Scholtz M, Kruger M, Saayman M (2015) Determinants of visitor length of stay at three coastal national parks in South Africa. J Ecotour 14(1):21-47

Sekercioglu CH (2002) Impacts of birdwatching on human and avian communities. Environ Conserv 29(3):282-289

Steven R, Smart JCR, Morrison C, Castley JG (2017) Using a choice experiment and birder preferences to guide birdconservation funding. Conserv Biol 31(4):818-827

Suarez-Rubio M, Thomlinson JR (2009) Landscape and patchlevel factors influence bird communities in an urbanized tropical island. Biol Conserv 142(7):1311-1321
Tengberg A, Fredholm S, Eliasson I et al (2012) Cultural ecosystem services provided by landscapes: Assessment of heritage values and identity. Ecosyst Serv 2:14-26

Tew ER, Simmons BI, Sutherland WJ (2019) Quantifying cultural ecosystem services: disentangling the effects of management from landscape features. People Nat 1(1):70-86

Whelan CJ, Şekercioğlu ÇH, Wenny DG (2015) Why birds matter: from economic ornithology to ecosystem services. J Ornithol 156(S1):227-238

Zoeller KC, Gurney GG, Heydinger J, Cumming GS (2020) Defining cultural functional groups based on perceived traits assigned to birds. Ecosystem Services 44

Zoeller KC, Gurney GG, Marshall N, Cumming GS (2021) The role of socio-demographic characteristics in mediating relationships between people and nature. Ecology and Society 26(3)

Publisher's Note Springer Nature remains neutral with regard to jurisdictional claims in published maps and institutional affiliations. 